Vol. 2, nº 1 | 1998

Varia

\title{
Meaning and social context of crime in preindustrial times : rural society in the North of Spain,17th and 18th centuries
}

Tomas A. Mantecón Movellán

\section{(2) OpenEdition Journals}

Electronic version

URL: https://journals.openedition.org/chs/992

DOI: $10.4000 /$ chs. 992

ISSN: 1663-4837

\section{Publisher}

Librairie Droz

\section{Printed version}

Date of publication: 1 January 1998

Number of pages: $49-73$

ISBN: 2-600-00279-0

ISSN: $1422-0857$

\section{Electronic reference}

Tomas A. Mantecón Movellán, "Meaning and social context of crime in preindustrial times : rural society in the North of Spain,17th and 18th centuries", Crime, Histoire \& Sociétés / Crime, History \& Societies [Online], Vol. 2, $n^{\circ} 1$ | 1998, Online since 03 April 2009, connection on 23 March 2022. URL: http://journals.openedition.org/chs/992 ; DOI: https://doi.org/10.4000/chs.992 


\title{
Meaning and social context of crime in preindustrial times: Rural society in the North of Spain, 17 th and 18 th centuries
}

\author{
Tomás A. Mantecón'
}

$T$ his article analyzes conflict, deviance and crime in Cantabria, a rural area of northern Spain in the 17th and 18th centuries. From an initial consideration of power and crime under the Ancien Régime and from the still young history of crime in Spain, this article goes into the explanation of the social meaning of crime, discussing Michel Foucault's theory of penal law. These pages are an itinerary through the analysis of social struggle and crime, social order and conflict and, the different uses of justice and social discipline. In conclusion only a few criminals are to be found in rural Cantabria of 1600-1800, but many social deviants, and this was due to the hybrid nature of both justice and crime. Judicial discipline was therefore not repressive. Where, then, was the invisible hand which articulated all the repressive apparatus of which Foucault writes?

Cet article propose une analyse des conflits, de la déviance et de la criminalité

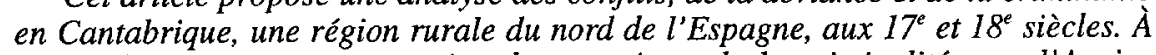
partir d'une mise en perspective du pouvoir et de la criminalité sous l'Ancien Régime, et en se fondant sur l'historiographie, encore récente, de la criminalité en Espagne, cet article entreprend d'expliquer la signification sociale du crime, en la confrontant à la théorie du droit pénal proposée par Michel Foucault. Il présente une analyse des relations entre conflit social, ordre social et criminalité, ainsi que des différents usages de la justice et de la discipline sociale. Cette étude montre qu'il y avait peu de criminels dans les campagnes de Cantabrique, entre l600 et

1 Thomás A. Mantecón Movellán, born in 1962, is assistant professor at the University of Cantabria (Spain), where he currently teaches Cultural History of Early Modem Europe. His main research interest deals with the social bakground of crime in the rural communities of Northern Spain. He is the author of: Counter-Reformation and Popular Religion in Cantabria during the Old Regime, the Religious Contraternities (Santander, Cantabria University Press, 1990 in Spanish); Social Struggle and Social Disciplining in the Rural Cantabria of the Old Regime (Santander, Cantabria University Press, 1997, in Spanish); Antonia Isabel Sánchez's Death: Tyranny and Scandal in the Rural Society of the North of Spain (Centro de Estudios Cervantinos, University of Alcalá de Henares, 1998, in Spanish). Many thanks to James Amelang, Teofanes Egido, José Ignacio Fortea, Ramón Lanza, Roberto López, Pablo Pérez García, Bernard Vincent and Keith Wrightson, René Lévy and the referees of Crime, His. tory \& Societies for their comments on points of this article at different times. The last version of this paper was written during Tomás A. Mantecón's stay as Visiting Member of Darwin College at the University of Cambridge (1995-1996), on a scholarship from the Spanish Education and Science Department. I am grateful to Sarah Wright and Mary Gedes for helping me with the translation of some parts of this article into English, and to Gema Lanza for supervising the final English version. I also thank my colleague Luis Teira for his help with the map enclosed in this article. $O$ Librairie Droz. 
1800, mais de nombreux déviants, et que ceci tenait au caractère hybride à la fois de la justice et de la criminalité. La discipline judiciaire n'était, dès lors, pas répressive. Où, dans ces conditions, était donc la main invisible, censée articuler tous les appareils répressifs, qu'évoque Foucault?

The study of crime in Ancien Régime society presents both theoretical and empirical problems. History of crime is a hybrid of legal history, political history and social history. This complication is far from slight, but it is not the only one by any means. To begin with, one must possess «the stomach of a vulture», as one acting attorney complained during the case against a Cantabrian cattle-rustler in 1789 , « in order to swallow the toads and snakes » which emerged in the judicial reports he was reading then. However, these documents have the most substantial empirical information for the history of crime $e^{2}$. In fact, depending on the quality of the judicial records, the infrajudicial sources can assume greater or lesser significance, but, in any case, they always have to be taken into consideration ${ }^{3}$.

These judicial reports offer rich information but, in exchange they demand hard work. This is not, however, the only difficulty that we have to overcome. There are also theoretical problems involved in delimiting the field of study. First, the concept of crime was changing in the preindustrial times. Second, crime meant different things in rural and urban areas, even in the same period. In practice, criminal behaviour was not defined by penal law alone, as judicial actions also reveal several versions of crime hidden by social tolerance. Lastly, the study of crime cannot be considered separately from the study of power in its various exercises. This is the first point to be explained in the following pages, before introducing the particular analysis of the meaning and social context of crime in the rural society of preindustrial times, and before illustrating this problem with the Spanish example of Cantabria.

\section{POWER AND CRIME UNDER THE ANCIEN RÉGIME}

The hybrid nature of the investigation of crime has given rise to unequal methods of analysis, related to two types of diverging explanations. Some historians have explained that the political and social systems expand more often than disintegrate. They also have defended the idea that the majority of societies have either adopted or, on the contrary, have competed with the forms of disorder and deviance existing in them $\mathrm{m}^{4}$. Other historians have challenged the principle that order is the natural and characteristic condition to which societies aspire. This last group of historians have also unmasked the powers that were developed by the states to repress those who might challenge their authority ${ }^{5}$. Whatever its focus, whether on integra-

\footnotetext{
A[rchivo] R[eal] C[hancillería] V[alladolid], Plleitos] C[riminales], C-187-4, ff. 182-184.

On infrajudiciality see Soman (1980).
}

4 This has been demonstrated by studies on Italian cities in the lower Middle Ages and also on wide areas of Finland and Scotland: Becker (1976); Ylikangas, (1976); Davis (1980); Wormald (1983); Lenman, Parker (1983). A good recent study is that by Lonni (1990).

5 As it has been explained by Foucault (1975), in a development of Durkheim's theory (1895). Durkheim and Foucault focus their attention on the structures of power in order to explain: solidarity and moral freedom (interiorized discipline, but moral and corporative), at times leading to anomy, according to Durkheim; individuality and coercion (repressive discipline), as Foucault thought. For both, 
tion, which is represented by the first group of historians, or on conflict, the second group, the study of the social significance of crime and the social and cultural environment of penal law, in the last years at least, has been showing that a complex, as opposed to mere institutional analytic, approach is essential ${ }^{6}$.

In spite of all these arguments, it is necessary to point out that, under the Ancien Régime, as in present day societies, a person could be considered as deviant not only for contravening legal requirements, but also for violating the boundaries of social compromise or tolerance which were commonly accepted in the society in which he lived and acted. We must also consider the perspective which was supported by the political thinkers of early modern history. During the 16th century, for instance, in the European regions of Germany, Italy and Spain, there was a very thorough-going reflection on the structure of power in society, from the ethical level of each person and the economic (oeconomica) level of the household (oikos) to the political level of the state or kingdom? . This theory depicted the state as a living organism in which each part (households and corporations) was self-governing in its own sphere. Nevertheless, this did not mean that each political circle within the body of the state was absolutely self-sufficient because, in all living organisms, each organ has its own functions, and each one performs those functions by itself; but, each one also needs the others in order to keep the body alive ${ }^{8}$.

By the end of the 16th century, from this generally accepted scheme, one of the most famed and prestigious Spanish judges, named Castillo Bovadilla, propounded a patriarchal theory in which he organised an ideal and harmonious pattern of society. In his view the concept of discipline could be understood as having a corrective function, not a repressive one, in the different spheres of power recognisable within the body of the monarchy'. At that time, there were different powers shared in the social body, and disciplinary capacities to correct the deviations in each sphere of power. Like order and deviance, discipline could have more than one manifestation in the early modern history of Europe. In practice, both law and custom, as well as theory, marked dividing lines between licit and illicit behaviour. Self-censorship and self-regulation were at times the causes and at other times the effects of the different discipline ${ }^{10}$. Both completed the series of controls in an anormative way. We

discipline was an instrument capable of producing men whose attributes are provided by power (docile bodies), according to a definition of illegality. Following on from this focus, some historians have carried their work further; particularly important are French historians like Farge (1992) or Muchembled (1989). These theories have also had a certain resonance in Spain, see Trinidad (1989). This perspective was a great step forward with respect to the statistics for the same years collected a decade earlier by the disciples of P. Chaunu. A classic example of the focus of the Normandy School is the article written by Boutelet (1962).

- Complexity, from this point of view, was explained some years ago by Lévy and Robert (1984, and in Spanish, 1990).

7 Brunner (1970); Oestreich (1982); Frigo (1985, 1986); Atienza (1991).

8 This metaphoric language was utilized, with anatomical details, by the Spanish thinker and physician, Cristóbal Pérez Herrera (1609), in one of his letters to the Spanish King. The letter proposed remedies for the bad health in which the kingdom found itself.

9 Castillo Bovadilla (1597, I, 1, 28-31). Which confirms, for the Spanish context, the theories of P. Oestreich (1982) on the practice of absolutism.

10 Respectively these two concepts are referring to the level of intrahuman control, as proposed by Elias (see Spierenburg's very clear explanation, 1995, p. 20-25). Nonetheless, both concepts also show that this level was connected to the interhuman one. 
will not go into this important question in this article, however, rather we are proposing to look at crime in the rural environment from the perspective of conflict, which was contained in each judicial case ${ }^{11}$.

This point of view allows us to discover the factors acting on self-censorship and self-regulation, on an individual level. There were, furthermore, outbursts of conflict in the social relationships, which triggered all the mechanisms of ordering and social control. These disciplinary mechanisms were set off to restore the health of the political organism. However, violence could be also one of the most important ties between people, especially in rural environments. In that sense, violence was power as well, because it was an aspect of some human relationships, particularly when it was used to impose ties of personal dependence ${ }^{12}$. This last issue refers us to an illicit version of discipline. According to all these arguments, the social meaning of deviance, conflict and crime was very complex; nevertheless, it is possible to gain a better understanding of these concepts from the regional perspective and from the local judicial documents.

\section{THE HISTORY OF CRIME IN SPAIN WITHIN THE EUROPEAN CONTEXT}

Besides the reflection on modern penal theories which was strongly rooted in the Renaissance predecessors of penal science, the preoccupation with knowing the size, typology and manifestations of crime has been constant in history of practically the whole of Western Europe throughout the 19th and 20th centuries ${ }^{13}$. Throughout the 19th century in almost all the Western countries of Europe, important contributions were made to the quantitative knowledge of crime and criminals. These contributions must be studied specifically. Although we will not undertake this kind of investigation now, we are able to estimate that those studies were made with more courage than scientific rigour ${ }^{14}$. Despite that, the inquiries of the 19th century established a very important substratum of reflection on the history of crime in different European societies and cultures. The complexity of this problem as a historical one has been discovered more recently, especially since the $1960 \mathrm{~s}$. Between the end of

11 The meaning of conflict in these pages is different from the «conflict theory » of crime which has been attributed to E.P. Thompson (Chapman, 1980, p. 139-155).

This was Elias's definition of power as he gave it to Peter Ludes, in an interview published in London in 1984 (I read the Spanish version in Elias (1994, p. 53-54).

13 Schafstein (1957).

14 In order to get a global idea, it is necessary to contrast different authors and countries. I am thinking of the criminal statistics in Madoz's Diccionario Geográfico-Estadístico-Histórico de España y sus posesiones de Ultramar, published between 1840 and 1850, and Pike's and Stephen's British treatrises on the history of criminal administration. Furthermore we must also think about « moral statistics" which were made by people in the circles of the Belgian and French governments in the 19th century. In Belgium, Quetelet's work, developed since the 1820's was one of them. In 1831, he wrote his Recherches sur le penchant au crime aux différents âges. Nevertheless, Quételet was not alone. The director of Criminal Affairs in the French Justice Department at that time, Guerry de Champneuf, and other «moral statisticians» such as Ducpetiaux in Belgium and d'Angerville in France published their opinions in the 1830s. This work was in line with the others just mentioned in England and in Spain. The studies by Mazzoni Toselli, Babotto, in Bolonia and Torino after 1835, took the same approach (see Chapman, 1980, p. 139-141; Robert, Lévy, 1984, p. 66-67 and Zorzi, 1989, p. 930, Pérez García, 1990a, p. 27-28; Mantecón, 1996). 
the 19th century and the 1960 s, French historiography had a very solid social history ${ }^{15}$.

Since 1967, the year in which François Billacois ${ }^{16}$ used the word criminality (criminalite), thus suggesting a new perspective, the history of crime has been growing in different fields, which can be summarized as follows: the study of theories about punishment; the arena of judicial administration and penal proceedings; research on the concept of crime as a complex field, a cross-roads of institutional, social and cultural history ${ }^{17}$. This last historiographical scene has offered many possibilities in more recent times. There are general studies and plans for future research ${ }^{18}$, we have national studies in the case of France ${ }^{19}$, England $^{20}$, Spain $^{21}$ and Italy ${ }^{22}$, but there are fewer national studies than regional or local ones ${ }^{23}$ and, lastly, we have microhistorical analyses of general problems linked with the history of crime, the history of deviance or their common trunk line ${ }^{24}$ : social and cultural history, or new history ${ }^{25}$.

In Spain, the history of crime began at the end of the 1960s. The first research came from political ${ }^{26}$ and legal history ${ }^{27}$. Later, five main trunk lines have been developed in the Spanish history of crime. The two lines which started this research in the sixties have furthered knowledge on the aims and the instruments of the monarchy for the practice of one of its exclusive powers, such as jurisdiction. These research directions have taught us about judicial proceedings ${ }^{28}$, the development of

15 Cf. the relevant contribution of Annales and historians like Bloch, Febvre, Braudel, Le Goff, Duby, Mousnier, Goubert, Ariès, Mandrou, Le Roy Ladurie, Bercé, Furet, Vovelle, Klapisch, Farge, Muchembled, Perrot, Chartier... and many more to the present social and cultural history in which the history of crime was slowly finding a place. The comment is similar for the Lampretch's contribution in Germany. After that, there came the studies by Brunner and more recently by Schilling or Jütte, from different perspectives. The same remark may be made about the contribution of British historians like Thompson, Hilton, Hill, Burke, Stone and many others. Billacois (1967, p. $340 \mathrm{ff}$ ).

17 See Lévy, Robert (1984).

18 See: Lévy, Robert (1984); Weisser (1979); Grendi (1980); Lenman, Parker (1983); Sbriccoli (1988, p. 491-501); Zorzi (1989, p. 923-965); Lonni (1990); Pérez García (1993); Rodriguéz (1995, p. 117 127); Mantecón (1996).

19 Abbiateci (1971); Muchembled (1992).

20 Amussen (1986); Goheen (1991).

21 Thompson (1992); Tomás y Valiente (1969); Weisser (1979); Kagan (1991a, b); Heras (1991).

22 Trasellin (1973, p. 226-246); Alessi (1979); Fioravanti (1982); Mantini (1988, p. 622 ff).

23 The list could be extraordinarily long. I think it is enough to remember the well-known studies of $B$. Boutelet, A. Margot, Y. Castan, R. Muchembled, N. Castan, C. Fouret, Ph. Henry or A. Farge in France; J.M. Beattie, J.S. Cockburn, C. Herrup, B. Lenman, G. Parker, J. Sharpe and J. Wormald... on England and Scotland; C. Ginzburg; M.A. Becker, G. Ruggiero, A.D. Wright, M. Romani ; C. Povolo and A. Parisini... on Italy; J. Rossiaud, A.M. Hespanha, or M.A. da Rocha Beirante in Portugal, H. Ylikangas in Finland and X. Rousseaux. All of these and others historians since the 1960s have shown the regional perspective to be the most productive one.

We have to remember here the work of several important historians from different countries in the European context: Ginzburg (1982); Davis (1982); Sabean (1987); Povolo (1988); Contreras (1991); Garnot (1993).

Concerning the «New History», see Burke (1993).

Thompson (1992).

Rodríguez Molinero (1959); Tomás y Valiente (1969).

For legal history, see in particular: Alonso (1982); Aikin Araluce (1982). 
judicial institutions and the administrative corps ${ }^{29}$, and even about the political use of criminal convicts and deviants in the army ${ }^{30}$ and the granting of royal mercy to convicts $^{31}$. Another line of research has been linked to the study of the inquisitorial courts $^{32}$, predominantly from the institutional and administrative viewpoint. Equally, there is a very strong analytical tendency, in the field of history of crime, connected with social history.

Concerning this last perspective it is necessary to say that there was a very important contribution to the social history of crime from the Mediterranean coast of Spain in the eighties. We can see the beginning in two important meetings: Actes du premier colloque sur le Pays Valencien (1980) and I Congrés d'Història de Catalunya (1984). There have been important antecedents in the study of justice and institutions since the end of the 19th century in Spain, even in this specific area ${ }^{33}$. What is certain is, first, that the earliest articles in this direction were published in the eighties, secondly, that most of them were part of research in progress at that time, and, last, some research from other Spanish areas yielded results at a later time ${ }^{34}$. This comment extends to some articles written at the beginning of the nine$\operatorname{ties}^{35}$. By this time some more thorough research had been done and a few of the results published. This was the case of the studies carried out by P. Pérez García, M.L. Candau, T. Ibars, J. Pérez Muñoz, T.A. Mantecón, I. Bazán, I. Almazán and others from Valencia, Andalusia, Catalonia, Estremadura, Cantabria and the Basque Country ${ }^{36}$.

The last direction in the Spanish history of crime is in the field of microhistory. At present, just two specific microhistorical studies have been carried out in this historiographical tradition, by R. Kagan and J. Contreras, but the prospects for the future are good ${ }^{37}$.

Spanish historiography on crime is becoming important in the European context. There are many avenues of research on crime in preindustrial times. We have enough theoretical reflection to move foward on the legal, social and cultural knowledge of crime. But more work is needed in order to establish typologies of crime and punishment from the legal perspective. Futhermore, we need to develop our knowledge of social and institutional arbitration and, linked to this, to explain the gap be-

29 Kagan (1991b); Heras (1991).

Pérez (1976); Trinidad (1989); Heras (1990).

Rodríguez (1971); Heras (1983).

There is a very long tradition of studies on this subject. We are writing about the most relevant publication in this field in the last two decades. See Escandell, Perez Villanueva (1984); Inquisicion española... (1987). The Biblioteca de Autores Cristianos (BAC) is presently publishing the second volume on the history of the Inquisition in Spain and America. Almost all Spanish historians who work in this field have participated in these books.

This question has been analysed by Moreno, Betrán (1995, p. 110-111).

Graullera Sanz (1980); Grau i Corbatera (1984); Ibars Chimeno (1984); Romero García, (1984); Almazán (1986); Quintana Toret (1989).

Almazán (1990); Suárez (1991); Almazán (1992); Reder (1992, 1993).

Peréz García (1990b); Pérez Muñoz (1992); Candau Chacón (1993); Mantecón (1997); Bazán (1995). Ibars' and Almazán's doctoral dissertations in this field haven't been published yet. Neither Alloza's on Madrid in the 18 th century.

Kagan (1991a); Contreras (1991). Recently Amelang (1995) has written about Spanish cultural conditions which lend themselves to microhistorical studies. From this perspective, see also the recent books of Lorenzo (1996) and Mantecón (forthcoming). 
tween the judicial sentence and its execution ${ }^{38}$. By contrasting social arbitration with the institutional form, we will refine the research not only on judicial practice but also and, overall, on the social world of criminals and victims. There is much to be done in the field of the social, moral and penal definitions and values which transformed a specific conduct into deviant or criminal behaviour. We also have to think about whether there were subcultural spheres of social deviance or exclusion. Lastly, we need to overcome a number of difficulties and try to make our information comparable with other European studies and with Spanish research as well, because, the most relevant problem in present-day Spanish historiography on crime is probably the various research perspectives in terms of time, space and focus.

\section{SOCIAL STRUGGLE AND CRIME IN CANTABRIA}

Cantabria is a rural area on the Northern Spanish coast between the sea and the mountains. Cantabrian territory borders were mobile until 1833 , the year in which they assumed their present contours because Cantabria was constituted as a province by law. Nevertheless, during the 17 th and 18 th centuries, the limits of this region between Asturias and the Basque Country were those drawn up by the episcopal dioceses in 1754. This territory included some seaports such as San Vicente de la Barquera, Comillas, Santander, Santoña, Laredo and Castro Urdiales. Santander became an important port because it was among the five Spanish ports licenses for colonial trade in the second half of the 18th century. This circumstance made the traffic of people and merchandise from Castile (Palencia and less from Burgos) to Santander more intense than before. Between these points, illicit trade driven by smugglers flourished, and this route was eventually struck by banditry. Nevertheless, the contact between Cantabria and the other regions of Castile was very close before the middle of the 18 th century. Moreover, some of these illicit activities also occurred in another area, which connected Castile with the Basque seaport of Bilbao through some valleys of Cantabria. This was because there were internal customs between the Basque Country (Señorío de Vizcaya) and Castile. These factors made it easy for some peasant-smugglers in Cantabria to conduct illegal trade.

There was, therefore, a very close historical relationship between Cantabria and the rest of Castile. During the 17th and 18th centuries, this was, moreover, linked to structural emigration from Cantabria, because this was the only way to maintain the high population density in this northern region of Spain. Those rates were, in any case, higher than in the rest of Castile. When we talk about emigration in this period we are referring particularly to peasants without land or with very modest properties: smaller than two hectares, or five acres, and divided into many plots in an openfield landscape. Two thirds of the rural population in Cantabria were in this situation in 1752. The peasants had another problem, which was the structural insufficiency of the cereal crop and illicit practices by local sellers in supplying cereal during the harshest times. In circumstances like these debt was a real risk; consequently, emigration was one way to escape from the threat of poverty. Temporary emigration to

38 On the former, see Rodríguez (1981, p 273-280); Mantecón (1990, p. 116-122; 1995a). On the last question, see Rodríguez's comments on Extremadura (1980), Pérez García looks at the evolution of the executioner's salary in Valencia at the end of the 15th and the beginning of the 16th century (Pérez García, 1990b), and my own considerations on Cantabria in Mantecón (1996). 
Castile or Andalusia was a help to these weak domestic economies. Less frequently, this led to the search for a permanent home in America ${ }^{39}$.

Temporary emigration always gave the Cantabrian peasant the opportunity of finding the financial means to cope with the most hostile junctures and, sometimes, the possibility of improving his social position. However, even at best, a healthy domestic economy implied the obligation for all the members of the household to work at agrarian and non-agrarian tasks ${ }^{40}$. This was the situation of the majority of the people living in the small towns and villages of Cantabria during preindustrial times and this, together with other causes, can help us to comprehend the high number of criminal cases we find in this area. Relationships between members of the family and between members of the village, or the rural community in general, could deteriorate when the ownership of land and other resources were limited by these structural factors or when the Castilian demand for labour diminished.

This last question does not fully explain how the judicial administration worked, but, it does provide information about some of the factors which brought the Cantabrian peasant before the court. Moreover, there were many situations in which the judge was able to calm discord between neighbours when the criminal matter was unimportant (insults or minor assault). These comprised the majority of his actions, and in most cases the conflicts were resolved without judicial sentence and out of court. Another important issue to be considered is that the judicial arm reached small districts, because, since the end of the Middle Ages, each valley of Cantabria had its own judge who represented the first judicial stage in civil and criminal matters. The cost of judicial litigation was greatly reduced for this reason, so it was not difficult to start proceedings even when the economic situation was unhealthy. Due to all these factors we have considerable empirical material for the history of crime.

Cantabria was not a political, jurisdictional, or social, or even territorial body before 1833. It was a cultural concept created out of the frequent opposition and fighting between, on one hand, the majority of the valleys between the mountains and the sea, and, on the other hand, the duke of Infantado, who was head of one of the most important aristocratic families in Castile. In the second half of the 15th century, the duke tried unsuccessfully to establish seigniory over the territory of the valleys. After that, the most relevant political, jurisdictional, social and territorial body of Cantabria was the valley. There were more than sixty small valleys and judicial districts in Cantabria during the 17th and 18th centuries. All these areas had to keep judicial records, but the majority have been lost. We can be sure of having a complete set from only three of these valleys: Alfoz de Lloredo, Reocín and Cayón. These documents are the principal source for our research on conflict, deviance and crime. This means consulting more than three thousand five hundred civil and criminal cases for 1600-1830, a third of which are criminal cases. This information has been completed with almost one hundred more trials which went on to the court of appeal (Chancillería de Valladolid). These resources are very rich not only in judicial information but also in social and cultural details. The records are of unique

39 The proportion of emigrants in the population of Cantabria was less than 3\% in 1752, or 2069 people: 287 emigrated to America (14\%), 456 to Andalusia (22\%), 131 to Castile $(6 \%), 169$ others (8\%), 1026 unknown (50\%). On these questions, see Lanza (1991, p. 387).

40 The most relevant evidence of this is in Le Play's research in 1840 (1990, p. 78-88), and in Lanza's study on the 1752 census $(1992$, p. 106, 112). About a third of the annual domestic income came from this sort of complementary or non-agrarian work. 
value because there is no relevant information about Cantabria in the Inquisitorial documents from the two courts in which this region was included: Logroño and Valladolid. Cantabria was a marginal area in the Inquisitorial structure and because of that the institutional and bureaucratic inquisitorial bodies were quite weak ${ }^{41}$.

From the framework explained and from Cantabria it is possible to expound the process of the definition of crime and related concepts, such as deviance and social discipline, in terms of practice ${ }^{42}$. In the same way, one may test the effectiveness of the models of integration or conflict for understanding the judicial interventions in the social environment under review.

\section{SOCIAL ORDER AND CONFLICT IN CANTABRIA}

In rural Cantabria of the 17 th and 18 th centuries, conjugal society implied the simultaneous constitution of a domestic power. This meant the recognition of the authority of the father and husband as well as the subjection to him of the other members of the household. The father of the family administered and governed the household autonomously, but not completely independently of the bilateral kinship group (parentela), nor were his powers unlimited in the face of the neighbouring community and the local judges. The patriarchal ties were projected from the domestic scene out onto wider spheres of government: bilateral kinship relationships, the village, municipal and valley communities. These links also governed the relationships between the different spheres of the community (village, council, valley or larger units) and between the local communities and the royal officers. The most powerful kinship groups depended on the capacity of their head to network and cement ties beyond their bilateral kinship group, forming factions around some local chieftain (cacique). This could be a member of an ancient lineage or a wealthy villager. The factions were composed of bilateral relatives of the group leader, servants, tenants, debtors, farm-workers, tenant-farmers or anyone who likely to lose their land from bad-harvests or other critical circumstances.

Words like relative (deudo), creature (criatura), protegé (paniaguado) and so on were used to describe the intermediary ties between household and community, thereby pointing out the existence of artificial relationships which became social and political pressure groups in the limited social spheres of the village, municipality and district. In this way, the kinship group in Cantabria was a fundamental sphere of political organisation throughout the 17 th century. The weak urbanization of this environment probably favoured a greater continuity in the functioning of these solid networks than in other more highly urbanized regions of Europe $e^{43}$. The whole framework depended upon the acceptance of the relationship between domination and consenting subjection. This formula was extended to encompass the communities of

41 Cristóbal (1987); Mier (1989). A new research by Marina Torres is now in progress on this topic, which should yeld userful information on the organization of local inquisitorial districts in Cantabria.

42 See Lonni's proposal on the concept of practice (1990).

43 As it had happened in the Genovese society studied by Raggio $(1986 ; 1990)$, who has recently synthesized his conclusions (1998) and has outlined the historiographical significance of kinship, a wider issue than that of the structure of the household, which was a focus of earlier historiography. This very complex matter, is also brought out by Wrightson writing on early modern England (1991) On self-help, see below, fn. 50 . 
which the household formed a part, for instance, the councils of one valley were considered «relatives». Furthermore, the judge had to intervene in the image of father of this global family ${ }^{44}$. For this reason, maintaining the position of the household and kinship group within the local community was decisive for complete access to shared rights and mutual aid. The councils had to manage their own affairs in the valleys and jurisdictions, but also in bigger associations of rural communities formed to develop common use of the land and to defend their community identity when it was threatened by illicit usurpers of collective rights. All of this meant that the principles of integration in each of these spheres could, in practice, became elements of friction. Order was sustained, therefore, by a fragile balance of tensions, resulting from daily «disturbances » between households, kinship groups, councils, valleys and usurpers.

The order projected by the political thinkers of this period as an overcoming of chaos, imbued with ethical values of the Counter-Reformation and which Castillo Bovadilla explained as being supported by patriarchal principles, was thus first of all expressed in the ranked areas occupied by each kinship group and each household in the temples, and also in the positioning of chapels and arms and shields. Furthermore there was an order which was agreed on by pact between the social bodies that were a part of each council and each valley. This became local law, which in Cantabria was recorded in written form in the Municipal Ordinances (Ordenanzas Municipales) and Edicts of Good Government (Autos de Buen Gobierno). There were also elements of order that were not written down in a systematic way, but which emerged in the judicial debates, between the allegations of plaintiff and accused. These were founded on immemorial custom, ancient or inviolate, and were particularly important in the case of a dispute in which common uses, resources or governmental and jurisdictional rights were menaced. All of this constituted a syncretic social perception of order and social deviance, the usurper of common rights representing a social deviation from the ideal of the good neighbour accepted within his village and valley. Crime, on the other hand, was defined by law, although certain crimes were tolerated by local custom, by the rural community and almost always by the judge, particularly those of a sexual nature, which reached the courts only when betrothals were broken.

Despite this flexible and syncretic perception of order, which generally was characterised by cooperative behaviour, the judicial proceedings presented a varied sample of infringements of community agreements and tolerance of the judges. The father of a family, for example, overstepped the border of his governmental powers within the domestic arena and attacked his wife, children and servants, took advantage of sexual "vulnerabilities" caused by the dependency of his maids. On other occasions these servants used the «weaknesses » of their powerful masters in order to gain judicially awarded compensation, as though it was a dowry, or other sort of benefits in exchange for their silence. Households comprised of bilateral kinship groups competed for the use of goods and resources from a lone common ascendants and for the successory rights enjoyed in associations formed by relatives for the use

44 The judge of Alfoz de Lloredo in 1636 ordered, following extrajudicial conciliation of the areas of $\mathrm{La}$ Busta and Rudagüera (two villages included in the judicial district of this valley) on the rights of pasture: "these two communities must be quiet and good and honest friends, because they have a sort of kinship link between them» [A(rchivo) H(istórico) P(rovincial de) C(antabria), A(lfoz de) L(loredo), leg. 80, doc. 5, s. f. (1636)]. 
of common resources (compañias de uso). Such tensions were manifested with great violence in the most extreme cases. Sometimes, women tried to extract their dowries from their progenitors, understanding the dowry as a better type of inheritance (mejoras), in spite of legal consideration and local tradition ${ }^{45}$. They then defended their position as strongly as when they had protected their dowries from the voracity of the moneylenders in the years subsequent to the time of crisis, when debt drove the weakest villagers into bankruptcy and left them at the mercy of mortgagees. At these times, too, the tensions surrounding the rights of administration of goods of absent relatives came sharply into focus, while the goods of minors suffered at the hands of their tutors.

These tensions arose within the household or within the kinship group. In the village sphere, the caciques used their powerful clientèle to intimidate, coerce or attack their opponents, thereby strengthening their «authority and seigniory " (dominio $y$ señorio) over their neighbours, in a way perceived as «tyrannical» by the rest. The village communities resisted illicit interferences in common rights. In this way they exercised a sort of factual, extrajudicial discipline over the kind of deviances these local and district tyrants practiced ${ }^{46}$. These aspects offer us a wide range of tensions and conflicts, but also of their recomposition through different types of negotiations, peaceful or conflictual; which demonstrates, on the one hand, that the organising principles of a patriarchal nature were in force at the time and in the place studied and, on the other, that these represented ideals for harmonious living, not just theoretical formulas. Patriarchy and the force of custom, as a systematic ideological agglutinate, offered instruments for the recomposition of order.

But there were also factors of conflict. What was, then, the role of the judges? Certainly there were many who managed to escape the arm of the law. The judges in the first instance resolved civil and criminal cases, but it was not essential for criminal proceedings to end in a sentence. The conflict could frequently be resolved by making use of an illicit discipline which was carried out by local caciques and factions. These groups could persuade plaintiffs of the expediency to withdraw the case from the court.

\section{THE USES OF JUSTICE AND SOCIAL DISCIPLINE}

The privacy of the violence exercised by the patriarchs was not legitimate if it crossed the boundaries of prudence. This version of violence was scandalous if it set a bad example, if bloody repercussions were feared, in short, if there were no ethical controls. In such cases the patriarchs intervened from above - from the domestic governors to the king. Of course, everything depended on how effective their influence was in tipping the balance in the favour of the judges and winning impunity. The impunity of the caciques was far-reaching, but not complete. It is true that they were not punished by the courts of justice, even when they had committed the crime of violent murder, and it is also true that they could circumvent a sentence they

45 (ovísima) R(ecopilación de las Leyes de España), laws 1-5, tit. 3, book 10. Lalinde (1978, p. 721 722); Peristany (1987, p. XXIX).

46 See Mantecón (1996). I develop the idea of tyranny as detachment from or damage to the community. Tyrants were usurpers of collective rights and violators of custom. 
did not like. However, this was dependent upon the strength and force of their group and its ability to intimidate the opposition. Actually, when scandalous behaviour, whether criminal or not, affected points as sensitive as collective uses and resources or the autonomy of the peasant community as a whole, then the case was sent to the high courts to be considered there, or else violent collective action could be taken, which, in turn, called for the intervention of the appeal courts ${ }^{47}$.

Whatever the likely outcome, the peasants of Cantabria almost always opted for extrajudicial solutions, even when the judge had taken part in the case. Some of the civil or criminal conflicts did not even reach the tribunals, as they were resolved by the religious brotherhoods $s^{48}$. Others reached the weekly mediations held by the judge and of which we have no written records of proceedings. The angriest conflicts came the attention of the local ( county») court judges. Very often those actions sought to restore verbal agreements which had been violated in some way. In other situations, the plaintiff sought judicial protection in the face of predictable violent acts from his opponents, above all if confrontation between kinship groups or the intervention of caciques was feared. In the affairs which reached the attention of the tribunals, it was most common for the case to end without sentence, but to be resolved with the mediation of the neighbours, parish priests or the judges themselves, who held interviews with the belligerent parties to reach agreement ${ }^{4}$.

In spite of the actual number of lawsuits, in fact only a small percentage of the crimes committed in the rural communities were brought to the attention of the royal courts. Of these, only a few were carried through to sentencing, and only a very small fraction of them were taken to the courts of appeal. The system which worked most commonly was that which involved extrajudicial negotiations, and, in these, judicial intervention was determined by the capacity of the parties to influence the mediators or to manage to stop proceedings by obtaining a waiver of the charges from the plaintiff. Despite that, we can draw valuable conclusions from observing the trajectory of the number of cases brought to court in the first judicial stage. There are in Cantabria three collections of complete and reliable lawsuits which correspond to the rural valleys of Reocín, Alfoz de Lloredo and Cayon. From the trend of criminal cases in these areas, we estimate that the agrarian crises of 1710-1730 raised the number of lawsuits, which had been growing since 1690, to a greater extent than in years preceding and in those that followed. The increase of the following years of the 18th century, which was in absolute numbers, corresponds with the continuous but slight growth of the population in the second half of the 18th century. This indicates greater social tension in 1710-1730 than even in the critical period at the end of the 17th century, although we find a noteworthy increase at that time too.

At the most critical points of the transition from the 17 th to the 18 th centuries, the hardships faced by the peasants put personal loyalties to the test. In these times, the erosion of personal links helps to explain the increasing number of judicial interventions. Arbitration in the disputes between peasants was reserved, then more than at other times, for the paternal mediation of the judges. The critical junctures strained personal loyalties within all social spheres: households, kinship groups, factions and peasant communities, even between valleys. The kinship group (parentela)

\footnotetext{
47

48

With Tilly's words (1976) these would constitute reactive collective actions.

This question is outlined in Mantecón (1990).

Mantecón (1995a, p. 149-156).
} 
made access to pecuniary loans easier; with or without private written contracts, they provided surety for agreements, or to pay bail. This solidarity made possible the creation of associations like compañias de uso. It was, in short, a variety of family aid for coping with threatening situations, which also helped when violent disputes took place with other kinship groups ${ }^{50}$. Nevertheless, shortages, when hard, long and widespread, caused many difficulties, even within these parentelas. At the same time, disputes over inheritance created a cohesion within the household which formed a part of the bilateral kinship group, and favoured the constitution of factions even within these groups.In general, insults, physical aggression, petty larceny and theft showed the judges the pulse which sustained the weakest domestic economies in times of shortage, lack and penury. The demands of creditors, appropriation of goods, the appropriation of community goods or the usurping of collective uses prolonged the conflicts beyond the critical years. In Cantabria, as in the other rural regions of France and England in the second half of the 18 th century ${ }^{51}$, the growth in population was followed by an increase in the absolute number of lawsuits, but this was not the most important factor in explaining this phenomenon, as can be verified by studying the relationship between the annual increase of criminal cases and the annual increment of population over the long term. It is easy to see that, during the second half of the 18 th century, the population of Cantabria increased annually more sharply than before, while the annual increment of criminal cases decreased even more abruptly. This trend cannot be explained from the social perspective because in Cantabria there was no process of institutional expansion of the administration of

Cantabria in the 17th and 18 th centuries

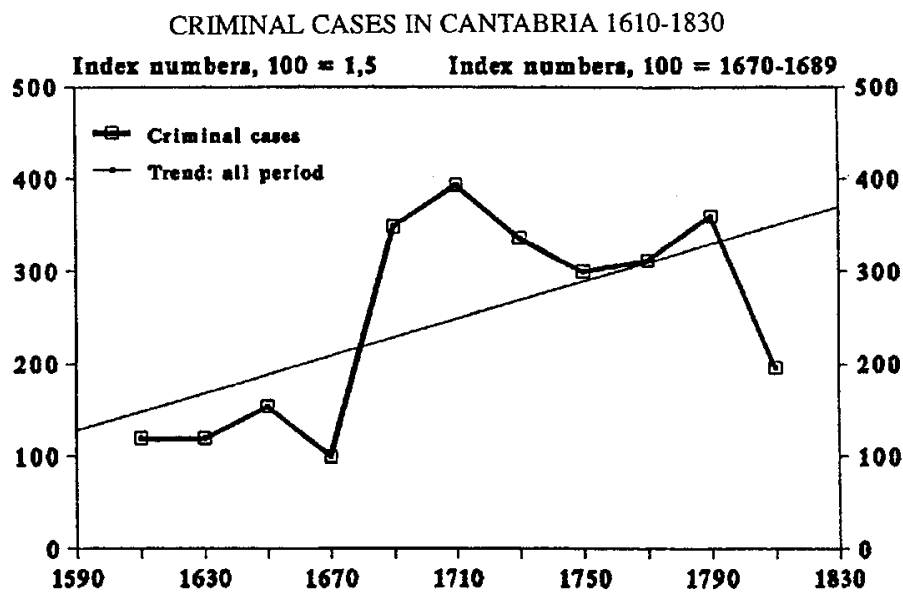

Population: Lanza, R., (1991), Criminal cases: AHPC, Cayón, Reocín, Alfoz de Lloredo (Cantabria).

so On self-help in Cantabria during this time, see Mantecón (1995b). For other regions of Europe, the most recent work is Dinges (1998). See also Jutte (1994).

51 As a contrast, see Neufchâtel at the second half in the 18th century (Henry, 1984), or Sussex and Surrey after 1718-1720 and from 1750-1760 (Beattie, 1974, p. 56 ff. and Henry, 1984). 
justice as, for example, in some British rural regions ${ }^{52}$. The most immediate reasons for the increase in lawsuits lay in the competition between nuclear families and kinship groups for the enjoyment of rights and uses, between different peasant communities for the exploitation of resources or the defence of their community autonomy in the face of usurpation by caciques and their groups of influence.

The harshness of the conditions endured by the peasant economy in some years highlighted the kind of behaviour which was understood to be damaging to the common interest. This motivated some communal protests. Although they did not go as far as the hunger strikes of Hampshire, Somerset Suffolk, Berkshire, Hertfordshire, Wiltshire and Kent between 1630 and 1650, or Essex in 1585-1660, or the revolts experienced in Russia, Poland, Central Germany and Bohemia, which were most critical during the second half of the 18th century ${ }^{53}$ we do find evidence of collective action, for instance, against the process of enclosure. These collective protests did not take place particularly when the council restrictions of participation and unequal participation in the ploughing (1610-1710) were combined with agrarian crises (1709-1712 and 1770-1810). This, in general, was a process similar to the one in others European regions; what is peculiar to this case is that the profusion of collective actions was greater in Cantabria when those circumstances were not present. The contrary phenomenon happened, for example, in England ${ }^{54}$.

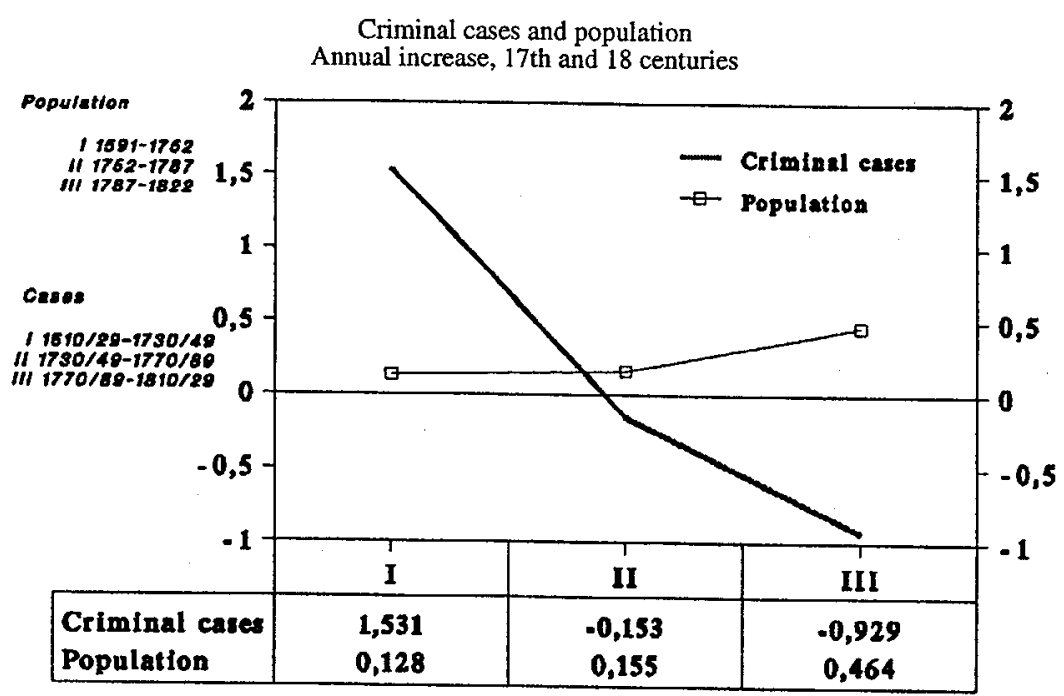

Population: Lanza, R., (1991), «Apendice 2». Criminal cases of districts of Reocín, A. Lloredo, Cayón.

52 Beattie (1986, p. 199 ff).

53 See Walter and Wrightson's article, (1984) for England in the 17th century. This argument is confirmed for the second half of the 18 th century by Bohsted and Thompson (quoted by Outhwaite, 1991, p. $47 \mathrm{ff}$ ), see also Thompson $(1979,1991)$. For Central and Western Europe, see Schulze, 1984, p. 75-82.

Manning (1988, p. 5) insists on the increasing harshness of the punishment for revolts and protests, parallel to the progression of the appropriation of communal goods; but the anti-enclosure protests were sharpened in the Kett Rebellion of 1549 , the effects of which became evident from the 1640 s onwards. 
This peculiarity of Cantabria is explained by the greater social participation in the ploughing process and the inverse relationship between the advancement of the process and the seasonal migrations, which fluctuated at the pace of the demand for work outside this rural region ${ }^{55}$. Almost ten thousand rural labourers depended on this and on credit, out of a census of slightly more than thirty three thousand people living in the same area in $1752^{56}$. There were also more than two thousand people who were considered beggars (pobres de solemnidad) and, apart from more than 3 $\%$ of what the census called masters of lineage (señores de linaje), sirs (dones) or, in short, well-to-do families, the rest of this population was constituted by tenant-farmers, peasant-labourers, peasant-sailors or emigrants. The rural society of Cantabria was not strongly polarised, but there did exist a broad fringe of peasantry who were in various situations and who gradually could become the victims of shortages if there were several consecutive critical periods and the possibilities of obtaining income were restricted.

In establishing comparisons between the examples of collective action in Cantabria and in other European regions, we should take some precautions, as there were many possibilities of community protest which were not well defined by Castilian legislation. John Walter and Keith Wrightson, for example, counted ten popular riots in Essex between 1585 and 1600; but, in spite of that, they had exceptionally welldocumented registers and were an area in which an intense process of enclosure had gone on. In just three valleys of Cantabria, with good registers, when the enclosures encroached further and further onto common land, between 1650 and 1670, there were four criminal cases concerning acts of contempt, disturbance and rabble, which, according to British parameters would count as riots, because the English legislation of the 17th century considered the gathering of three or more persons to be an illegal act by common consent ${ }^{57}$. If we use the same criteria in rural Cantabria many furtive tree-fellings, bark-strippings, forest-fires and all public disturbances would count as riots, and the figures would be much higher than the British one $\mathrm{s}^{58}$. In any case, what is certain is that the objectives and the victims of these kinds of extremely harsh negotiations were not fortuitous, and the violence was not unlimited. Under the umbrella of collective interests, quite often other interest emerged. The different catalysts of conflict could be the kinship group or parentela, the clientèle (clientela) or the peasant community. Each of these spheres was not only a circle of sociability and self-help, but also of social competition. Therefore, in all of those circles of sociability, public order was not only articulated, it was also broken up.

In a less intense form than before, these factors were in operation at the end of the Ancien Régime. However, there were other, new factors of conflict. I refer, par-

55 See Lanza (1991, chap. III).

56 This information comes from the following documents and bibliography: AHPC, C(entro de) E(studios) M(ontañeses), leg. 19, doc. 8 (1737-1743); Maza (1953-1961) which features a very complete edition for the Cantabria region of one of the most important Spanish census of the 18th century, the Catastro de Ensenada of 1752; Lanza (1991, p. 144), for this valley of Camargo in 1752; Ceballos (1991, p. 342) for the Guriezo valley in Cantabria, 1752.

57 British law continued being restrictive almost a century after the Riot Act of 1715 because each illegal action involving twelve people or more was considered a public disturbance (Walter, Wrightson, 1984, p. 110 ff.; Outhwaite, 1991, p. 45).

58 After 1766 the same would have applied to Castile. This was stipulated in the following laws: Auto of May 5th, 1766, Cédula of October 2nd, 1766 and Pragmática of the April 17th, 1774. These laws are to be found in N.R. laws 3-5, tit. 11, book 12 and law 8, tit. 25, book 12. 
ticularly, to the period encompassed by the bad harvests of 1775-1789 and 18031804, the wars with France and England and the increase in the fiscal demands owing to higher expenditures for the coastal fortifications in those times, and just before the Napoleonic invasion. The stopping of ploughing and the agrarian crises due to climatic factors, war, and shortages, above all in 1789 and 1803-1804, meant that circumstances worsened. However, following the first decades of the 18th century, robberies in the household of local wealthy property owners, occupation of and damage to goods, demolition of the «demarcation posts and reserve-lines» and towers of aristocratic lineages, clandestine tree-fellings, bark-strippings and intentionally started forest fires offered a very clear symptomatology of the state of the negotiations between the peasant communities and the usurpers of collective rights.

These symptoms were fully confirmed in the second half of the 18 th century. The peasant communities resisted, through forest-fires and furtive tree-fellings, the privileged use which the manufacturers of artillery and naval construction for the Crown made of the forest reserves and scrubs where the communities had rights of use. The latter (scrubs) were used customarily by the peasants to increase their production of fertiliser, and the former (forest) for the construction and the manufacture and sale of tools. The people of Cantabria also resisted the levies and increases in royal fiscal duties, but the most expressive indication of the communal nature of these resistances was the protection offered by the neighbours of the clandestine tree-fellers and the arsonists. In fact, their actions brought the peasant community back to collective uses which had been usurped by the iron-founders, the manufacturers of boats and the makers of artillery.

In this context, bandits posed a specific problem. Since the end of the 17 th century and particularly after the middle of the 18th century, these outlaws carried out a kind of usurpation of rights and properties in ways different to the caciques and the other cases studied. Bandits presented a problem for the rural communities; however, they also affected interests outside the peasant community. Since the mid-18th century, the port of Santander, as one of the five in Spain which could drive the trade between Spain and the American colonies, had been responsible for increasing the transit of persons and merchandise through the arteries of Castile, Santander and the West Indian destinations. This offered greater opportunities for the activity of bands of highwaymen. The majority of the perpetrators combined their criminal lives with temporary jobs in the valleys of the so-called «Flour Route» (Camino de las Harinas), which linked the Castilian city of Palencia with the seaport of Santander. The commercial impetus which the city of Santander enjoyed after the liberalisation of colonial trade, above all in the $1770 \mathrm{~s}$, and consequently its wider integration into the extra-regional market, favoured the increase in robbery and banditry in this area. There were many possibilities for these activities, from the appropriation of goods taken from houses to frequent assaults on the roads, cattle rustling or smuggling from Santander and the Basque ports towards Castile.

The city of Santander attempted to protect persons and merchandise from robbery, setting up disciplinary initiatives to reduce banditry and acting on vagrancy as a preventive way of fighting against the former ${ }^{59}$. From the 1720 's, the principle roads were guarded by small parties of soldiers. The chief magistrates (corregidores), in their circulars and dispatches to the local judges of the valleys, dissemi-

59 I have developed this point in Mantecón (1995c). 
nated propaganda about bandit cruelty and danger. This, they hoped, would instigate a preventive self-control in the rural communities. This was an effort to combat, before it emerged, a possible penchant on the part of the peasantry for the deviant life of banditry. The magistrates' attitude was not just a warning against the possible presence of dangerous murderers. The most notorious outlaws were as capable of infusing terror in the people and valleys as they were capable of interfering in the actions of justice. The participation of the local communities in denunciation and persecution facilitated the arrests of the outlaws and their conduct to secure prisons. What imposed a limit on the bandits' capacity to intimidate was the perception of them as a community problem. The institutional deficiencies that emerged after the arrest stage were linked to the problem of which district must pay the costs that the prisoner occasioned while in jail. This was an important question, capable of giving rise to long debates.

In the second half of the 18th century, Cantabria was going through a process of redefining patriarchy and order, but this was not made explicit in the edicts of the chief magistrates, the local law and the banns and pastoral letters of the bishops until after the French invasion. During the Gallic occupation of Cantabria, the definition of patriarchy stressed public order, the security of persons and goods, maintaining the paternalistic image of the governors. After the war between Spain and France (1808-1813), two opposing political models - absolutist and constitutional - defined order, but a new stimulus was needed to invigorate the social body. And social policy needed to promote work and the defence of property. Thieves, cattle-rustlers, smugglers and bandits were called «destructive larva » in the villages and «enemies of public peace», who ought to «be exterminated ». In the same way, vagabonds had to be sheltered in order to correct and assist them, because they easily fell prey to the negative example of the bandits. This new order had moved the needle of the police compass, associating deviance and danger, advancing in the protection of property and in the definition and prosecution of crime.

\section{THE SOCIAL MEANING OF CRIME}

In the preceding pages, we have seen that there were few criminals in rural Cantabria in the 17th and 18th centuries, however there were many social deviants. Few people were sentenced in criminal courts, but many more were protagonists of actions which merited intervention on the part of the judge. This meant that, over two hundred years, there were many criminal lawsuits, but not as many as might have emerged from the daily social frictions either of a horizontal or a class nature. Everything indicates that, in rural society in Cantabria, there was a broad margin of extrajudicial regulation, without this being of importance for the activity of judges and tribunals, because they complied with a fundamental commitment in the negotiations between parties in conflict. Was judicial discipline repressive, as Foucault thought? The answer seems clear: no. Was the discipline exercised by kinship groups, bands and factions repressive? The answer is not so clear: sometimes yes and sometimes no. This answer leads us to another question: when we talk about crime, what was the line between repression and discipline? It is not easy to answer this. In attempting to do so, we can refer to the ambiguity of a word which was used in the courts in connection with ideas such as «good father», «good neighbour» or 
«good judge»: this word is «prudence». For this reason it is vital to explain the concept of prudence.

In my opinion, in the word «prudence», lies the limit established in practice between criminal behaviour and non-criminal behaviour. If the actions were imprudent, they would be understood as deviant from the common ideal of good relations between neighbours. If a behaviour were so imprudent that it became scandalous, it could be punished by the community and, of course, if it was criminal, by the judge. An example can help us to explain this matter. Sexual crimes, aggressions and insults were the most common crimes brought before the judicial courts. With respect to the former, the convergence of criminal and canonical legislation on this point permitted a better typification of punishable behaviour. For this reason, sexual crimes offer us the clearest contrast between criminal theory and social practice. Were the unmarried people who carried on an extramarital sexual relationship breaking the law? Were the married men who had sexual relations with several local girls committing criminal acts? What kind of people were the women involved in these acts? Were all of them delinquents? and the prostitutes, were they criminals? What about their clients? All of these people were committing a crime according to penal law, but were they all deviants ? They were deviants only if their conduct surpassed the tolerance of their neighbourhood. If this happened the action would be scandalous and would soon be punished by the community or by the local court. In the last case, deviance then became crime. It could be interesting to investigate these questions in more detail.

The authors of extramarital sexual acts between unmarried people were not breaking the law if they were engaged to be married, for the engagement to be married, in practice, was considered to be a state of matrimony. The only thing this union needed, to be a perfect marriage, was the ecclesiastical legitimation. In fact, the couple were commonly considered to be married. The sexual relationship could also be the consequence of mere erotic games. The former and the second cases were conduct legitimated by custom ${ }^{60}$. There was a criminal act only if a matrimonial promise between the lovers had been broken, or if a pecuniary agreement between the parties could not be achieved in accordance with the value of the rape committed on the female (compensation for the loss of maidenhood). If the judicial case did not reach sentencing, that is, if an agreement was reached out of court, then the condition of deviant behaviour disappeared and also the possibility of criminality.

The situation in which a married man carried on sexual relations with several local girls offers more doubts. Adultery was a crime envisaged in Castilian law from the Partidas of Alfonso X The Wise in the Middle Ages. What happened in practice? Generally, adultery was tolerated if the wife allowed it, if the illicit sexual relationship was not publicly known and, therefore, if it did not set a bad example of conduct for other girls of the community. What would make the situation scandalous? The pregnancy of the concubine. Who was the deviant in this case? Both parties. Nonetheless, if the deviance was caused by the public notoriety of this behaviour and not just the knowledge by some but by the whole community, how was this avoided? By hiding the pregnancy, preventing maternity or abandoning the illegitimate child, depending on the power of the male to silence the gossip of neighbours. The

60 More concrete information on sexual behaviour in the traditional society of Cantabria can be found in the first part of Mantecón (1997). 


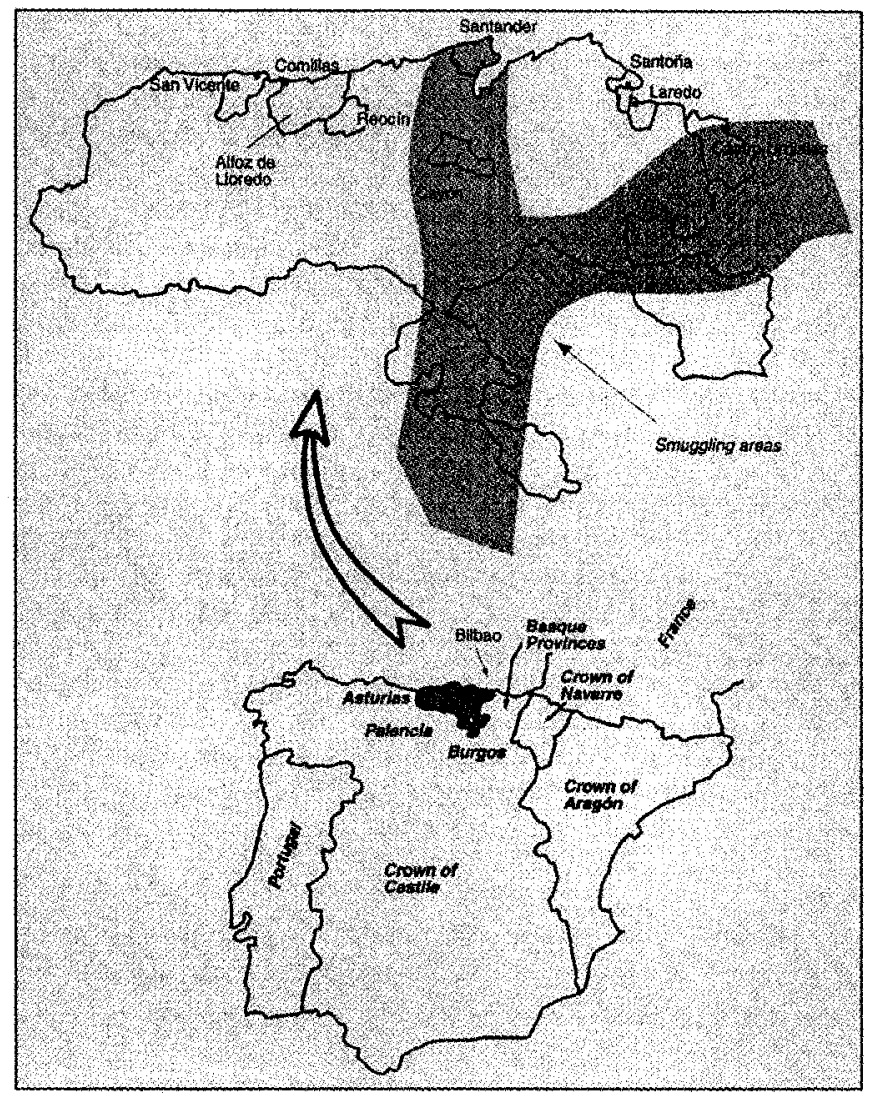

notoriety of the «bad action» marked a boundary in community tolerance, but generally there was only one deviant and presumed criminal: the girl. The male usually managed to buy the silence of his concubine and, occasionally, the false testimony of some bachelor male in the neighbourhood or a passing stranger.

Lastly, the case of prostitution represented one step further down the ladder. Clearly, in this case, the judge knew who the deviant was: the prostitute. She was a criminal by law, but how did the woman become involved in such criminal actions? and, when did she become a delinquent? Only when it was proven that she had not discriminated between bachelors and married males for her sexual commerce, then she was deviant in the public opinion. Only in this last case was she accused and sometimes condemned as a prostitute ${ }^{61}$.

Throughout this article and, particularly, in the last paragraphs, which show the social consideration of sexual crime, we can see there existed an enormous distance between the legal interpretation of an act and the daily social limits which actually

61 A specific study of the process of being declared a prostitute in this rural society is found in the third part of Mantecón (1997). 
decided whether these acts had to be considered criminal or not. In this way we can set out two prerequisites for defining crime in a rural society of preindustrial times. These requisites were, first, the prudence of the alleged criminals in avoiding scandal and, second, community tolerance. Nevertheless, there was yet another important point that must be considered: the social hierarchical order. This silenced or accentuated the assessment of a certain behaviour as illegal and criminal. This last point shows that some could be favoured over the greater part of the rural population. Different instruments of domination and the capacity to articulate a strong and extensive social network of clients around a patron or cacique, a local official of the Inquisition, a prosperous merchant or the owner of small businesses in Andalusia... allowed one to avoid community labelling as a criminal in these cases, whether due to favour or a capacity to intimidate others. On the other hand, custom offered some opportunities of class solidarity for the peasant community, for resisting the usurpations in which these tyrants and local caciques participated.

Who was responsible for the movement of the repressive regime that Foucault attributed to the penal systems of the Ancien Régime? Where was the invisible hand which moved all this supposedly repressive structure? In the rural Cantabria of those times, the explanatory axis did not lie in the relation between repressive governors and docile subjects, as deduced in Foucault's scheme. The axis was more complex than that: beneath an administrative apparatus of the Crown, there lay theoretical justifications, local laws and customs which left a deep imprint on judicial administration. This theoretical underworld was also influenced in a decisive way by the interests of the different social groups. A socio-historical or historico-social focus, and not a purely theoretical one, an analysis based on social practice around the concept of crime and not just the institutions, an examination of the execution of sentences and not simply their pronouncement, and a study of the social relations in each social structure and their sensitivity to change over a long period of time, all of these perspectives are making the hands which distributed discipline, at times repressive and at other times corrective, more visible. At least in Cantabria, discipline was not repressive if it came from the Crown, but it could be on the part of social forces which occasionally used instruments to exercise powers which were illegitimately usurped from the rural communities or the Crown. Nonetheless, as we have seen, these were also ways for rural communities to limit the attempts at tyrannical domination by the local caciques. All of this leads me to defend, with Giovanni Levi $^{62}$, not a religious, but a sociological interpretation of a libero arbitrio, as the judicial documentation and infrajudicial documents and information show wide margins of action in the hands of groups, factions and peasant communities.

Tomás A. Mantecón Movellán

Universidad de Cantabria

Facultad de Filosofia y Letras

Departamento de Historia Moderna y

Contemporánea

Avda de los Castros $s / n$

39005 Santander, España

(Mantecot@ccaix3.unican.es)

62 Levi (1993, p. 24). 


\section{REFERENCES}

Abbiateci, A. et al., Crime et criminalité en France aux XVII et XVIII ${ }^{\mathrm{e}}$ siècles, Cahier des Annales, 1971, 3.

Aikin Araluce, S., El recurso de apelación en el derecho castellano, Madrid, 1982.

Alessi, G., Prova legale e pena. La crisi del sistema tra evo medio e moderno, Naples, 1979.

Almazán, I., Delito, justicia y sociedad en Catalunya durante la segunda mitad del siglo XVI: aproximación desde la bailía de Terrasa, Pedralbes, 1986, 6, p. 211-216.

Almazán, I., El recurso a la fuerza. Formas de violencia en el Vallés occidental durante el siglo XVI, Historia Social, 1990, 6, p. 89-103.

Almazán, I., Penas corporales y disciplina social en la justicia catalana de los siglos XVI y XVII, Pedralbes, 1992, p. 127-148.

Alonso, M.P., El proceso penal en Castilla (siglos XIII-XVIII), Salamanca, 1982.

Amelang, J.S., Microhistory and its Discontents: the View from Spain, in Barros, C. (ed.), Histora a debate II. Retorno del sujeto, Santiago de Compostela, 1995, p. 307-314.

Amussen, S.D., Crime, loi et justice rurale en Angleterre à l'époque moderne, Études Rurales, 1986, 103-104, p. 47-69.

Atienza, I., Teoría y administración de la casa, linaje, familia extensa, ciclo vital y aristocracia en Castilla (s. XVI-XIX), in Familia, grupos sociales y mujer en España (s. XV-XIX), Murcia, 1991, p. 13-47.

Bazán, I., La criminalización de la vida cotidiana. Articulación del orden público y del control social de las conductas, in La vida cotidiana en Vitoria en la Edad Moderna y Contemporánea, San Sebastián, 1995, p. 113-168.

Beattie, J.M., The Pattern of Crime in England, 1660-1800, Past and Present, 1974, 62, p. 4795.

Beattie, J.M., Crime and the Courts of England, 1600-1800, Oxford, 1986.

Becker, M.B., Changing Patterns of Violence and Justice in Fourteenth- and Fifteenth-Century Florence, Comparative Studies in Society and History, 1976, 18, p. 281-295.

Billacois, F., Pour une enquête sur la criminalité dans la France d'Ancien Régime, Annales ESC, 1967, XXII, p. 340-349.

Boutelet, B., Étude par sondage de la criminalité dans le bailliage de Pont-de-I'Arche (XVII XVIII ${ }^{\complement}$ siècles), Annales de Normandie, 1962, 4, p. 235-262.

Brunner, O., Per una nuova storia costituzionale e sociale, Milan, 1970 (1st ed. 1968).

Burke, P., Overtura, Formas de escribir historia, Madrid, 1993 (1st ed. 1991).

Candau Chacón, M.L., Los delitos y las penas en el mundo eclesiástico sevillano del XVIII, Sevilla, 1993.

Castillo Bovadilla, J., Política para corregidores y señores de vasallos, 1597 (Madrid, 1978).

Ceballos, C., Estructura demográfica y movimientos migratorios en el valle de Guriezo en el Antiguo Régimen (unpublished dissertation, University of Cantabria), Santander, 1991.

Chapman, T.L., Crime in Eighteenth Century England: E.P. Thompson and the Conflict Theory of Crime, Criminal Justice History, 1980, 1, p. 139-155.

Contreras, J., Sotos contra Riquelmes. Regidores, inquisidores y criptojudios, Madrid, 1991.

Cristóbal, M.A., La inquisición de Logroño: una institución de control social, in Inquisición española. Nuevas aproximaciones, Madrid, 1987, p. 127-158.

Davis, N.Z., Le retour de Martin Guerre, Paris, 1982.

Davis, S.J., The Courts and the Scottish Legal System, 1600-1747: the case of Stirlingshire, in Gatrell, V.A.C., Lenman, B., Parker, G. (eds.), Crime and the Law. The Social History of Crime in Western Europe since 1500, London, 1980, p. 120-154. 
Dinges, M., Self-help and Reciprocity in the Parish Relief System, in Horden, P., Smith, R., (eds.), The Locus of Care: Communities, Caring and Institutions, London,1998.

Durkheim, E., Les règles de la méthode sociologique, Paris, 1895 (1st edition).

Elias, N., Conocimiento y poder, Madrid, 1994.

Escandell, B., Pérez Villanueva, J. (eds.), Historia de la Inquisición en España y América. I. El conocimiento científico y el proceso histórico de la Institución (1478-1834), Madrid, 1984 (Biblioteca de Autores Cristianos).

Farge, A., La vie fragile. Violence, pouvoirs et solidarités à Paris au XVIII ${ }^{\grave{m} e}$ siècle, Paris, 1986.

Farge A., Vivre dans la rue à Paris au XVIII ${ }^{\text {eme }}$ siècle, Paris, 1992.

Fioravanti, M., La scienza giuridica: il dibattito sul metodo e la costruzione della teoria giuridica dello stato, $I l$ pensiero politico, 1982, XV, 1, p. $92 \mathrm{ff}$.

Foucault, M., Surveiller et punir, Paris, Gallimard, 1975.

Frigo, D., Il padre di famiglia. Governo della casa e governo civile nella tradizione dell'economica tra Cinque e Seicento, Rome, 1985.

Frigo, D., Amministrazione della casa e amministrazione della società nella letteratura politica d'antico regime, Amministrare, 1986, XVI, 1.

Garnot, B., Un crime conjugal. L'affaire Boiveau, Dijon, 1993.

Ginzburg, C., El queso y los gusanos. El cosmos según un molinero del siglo XVI, Barcelona, 1982 (1st ed. 1976).

Goheen, R.B., Peasant Politics? Village Community and the Crown in Fifteenth-Century England, American Historical Review, 1991, 96, 2, p. 42-62.

Grau I Corbatera, J., Criminalitat i delinquencia durant el segle XVII a Osona: la violéncia generalitzada, I Congrés d'Història de Catalunya, Barcelona, 1984.

Graullera Sanz, V., Un grupo social marginado: las mujeres públicas (el burdel de Valencia en los siglos XVI y XVII), Actes du premier colloque sur le Pays Valencien, Valencia, 1980.

Grendi, E., Per lo studio della storia criminale, Quaderni Storici, 1980, 44.

Henry, Ph., Crime, justice et société dans la Principauté de Neufchâtel au XVIIT siècle (17071806), Neufchâtel, 1984.

Heras, J.L., Indultos concedidos por la Cámara de Castilla en tiempos de los Austria, Studia Historica, 1983, I, 3, p. 115-141.

Heras, J.L., Los galeotes de los Austrias: la penalidad al servicio de la Armada, Historia Social, 1990, 6, p. 127-130.

Heras, J.L., La justicia penal de los Austrias en la Corona de Castilla, Salamanca, 1991.

Ibars Chimeno, T., La delincuencia en la Lérida del siglo XVI, I Congrés d'Història de Catalunya, t.I, Barcelone, 1984, p. 457-462.

Inquisición española. Nuevas aproximaciones, Madrid, 1987.

Jütte, R., Poverty and Deviance in Early Modern Europe, Cambridge, 1994.

Kagan, R.L., Los sueños de Lucrecia, Madrid, 1991 (1st ed. 1990) (a).

Kagan, R.L., Pleitos y pleiteantes en Castilla. 1500-1700, Valladolid, 1991 (1st ed. 1981) (b).

Lalinde J., Iniciación histórica al derecho español, Barcelona, 1978.

Lanza, R., La población y el crecimiento económico de Cantabria en el Antiguo Régimen, Madrid, 1991.

Lanza, R., Camargo en el siglo XVIII, Santander, 1992.

Le Play, F., Campesinos y pescadores del Norte de España (1840), Madrid, 1990 (ed. by J. Sierra). 
Lenman, B., Parker, G., Il controllo del crimine in Scozia dal 1500 al 1800, in Il potere di giudicare. Giustizia, pena e controllo sociale negli stati d'Antico Regime, Cheiron, materiali e strumenti di aggonnamento storiografico, 1983, 1, 1 p. 71-83.

Levi, G., Antropología y microhistoria: conversación con Giovanni Levi, Manuscrits, 1993, 11,24, p. 16-28.

Lévy, R., Robert, Ph., La sociologie et l'histoire pénale, Annales ESC, 1984, 2, p.400-422 (tranlated into Spanish as: Historia y cuestión penal, Historia Social, 1990, 6, p.47-88).

Lonni, A., Dalla prassi alla norma. Criteri di definizione e di repressione delle azioni proibite (secoli XVIII-XIX), in Emarginazione, criminalità e devianza in Italia, 1990.

Lorenzo, F., Monjas y beatas, Zamora, 1996.

Manning, R., Village Revolts. Social Protest and Popular Disturbances in England, 15091640, Oxford, 1988.

Mantecón, T.A., Contrarreforma y religiosidad popular en Cantabria. Las cofradias religiosas, Santander, 1990.

Mantecón, T.A., La capacidad del clero secular para apaciguar las disputas entre los campesinos montañeses del siglo XVIII, in Martínez, E., Suárez, V, (eds.), Iglesia y Sociedad, Vol.I (III Reunión Científica de la Asociación Española de Historia Moderna), Las Palmas de Gran Canaria, 1995, p. 149-156. (a).

Mantecon, T.A.: The Gift Economy of Kinship in the Rural Communities of the North of Spain, 17th and 18th Centuries, Contribution for the International Conference Family, demography and social reproduction, (18th International Congress of Historical Sciences), Montreal, Aug./Sep. 1995 (b).

Mantecón, T.A., Extinguir a los bandidos en la Cantabria rural del siglo XVIII. Alcance de una intromisión urbana, Unidad y Diversidad en el Mundo Hispánico del siglo XVIII, Madrid, 1995, p. 878-888 (c).

Mantecón, T.A.: Desviación, disciplina social e intervenciones judiciales en el Antiguo Régimen, Studia Historica, 1996, XIV, p. 223-243.

Mantecón, T. A., Conflictividad y disciplinamiento social en la Cantabria rural del Antiguo Régimen, Santander, 1997.

Mantecón, T.A., La muerte de Antonia Isabel Sanchez. Tiranía y escándalo en una sociedad rural del Norte de España, Centro de Estudios Cervantinos, Univ. de Alcala de Henares (forthcoming).

Mantini, S., Istituzioni giudiziarie e criminalità: un dibattito pisano, Ricerche storiche, 1988.

Maza, T., Nobleza, hidalguía, profesiones y oficios en La Montaña, según los padrones del Catastro del Marqués de la Ensenada, Santander, 1953-1961, (4 vols.).

Mier, E., La Inquisición en las Asturias de Santillana o la mirada de Acteón, in Ilustraciones cántabras. Estudios Históricos. Homenaje a Patricio Guerin Betts, Santander, 1989, p. 279-308.

Moreno, D., Betrán, J.L., Justicia criminal y criminalidad en la Cataluña moderna: estudios y perspectivas de investigación, in Barros, C. (ed.), Historia a debate. II. Retorno del sujeto, Santiago de Compostela, 1995, p. 103-116.

Muchembled, R., La violence au village. Sociabilité et comportements populaires en Artois du XV au XVII siècle, Turnhout, 1989.

Muchembled, R., Le temps des supplices. De l'obéissance sous les rois absolus (XV'-XVIII siècles), Paris, 1992.

Oestreich, G., The Structure of the Absolute State, in Neostoicism and the Early Modern State, Cambridge, 1982 (1st ed. 1969), p. 258-273.

Oestreich, G., Polizia (Policey) e prudentia civilis nella società barocca della città e dello Stato, in Schiera, P. (ed.), Filosofia e costituzione dello stato moderno, Naples, 1989 (1st ed. 1974), p. 213-232. 
Outhwaite, R.B., Dearth, Public Policy and Social Disturbance in England, 1550-1800, London, 1991.

Pérez, R.M., El problema de los vagos en la España del siglo XVIII, Madrid, 1976.

Pérez García, P., Una reflexión en torno a la historia de la criminalidad, Revista d'Historia Medieval (Violència i marginació en la societat medieval), Valencia 1990, p. 11-37 (a).

Pérez García, P., La comparsa de los malhechores. Un ensayo sobre la criminalidad y la justicia urbana en la Valencia preagermanada (1479-1518), Valencia, 1990 (b).

Pérez García, P., Desorden, criminalidad, justicia y disciplina en la Edad Moderna temprana: problemas abiertos, in Alvarez, L.C., Cremades, C.M. (eds.), Mentalidad e ideología en el Antiguo Régimen (II Reunión científica, Asociación Española de Historia Moderna), vol. II, Murcia, 1993, p. 93-118.

Pérez Herrera, C., Al católico rey de las Españas... en razón de muchas cosas tocantes al bien, prosperidad, riqueza y fertilidad destos reynos..., Madrid, 1609.

Pérez Muñoz, J., Pecar, delinquir y castigar: el tribunal eclesiástico de Coria en los siglos XVI y XVII, Cáceres, 1992.

Peristany, J.G., Dote y matrimonio en los países mediterráneos, Madrid, 1987.

Povolo, C., Processo contro Paolo Orgiano e altri, Studi Storici, 1988, XXIX, p. 321-360.

Quintana Toret, F.J., De los delitos y las penas. La criminalidad en Málaga y su tierra durante los Siglos de Oro, Estudis, 1989, 15, p. 245-269.

Raggio, O., La politica nella parentela. Conflitti locali e commissari in Liguria Orientale (secoli XVI-XVII), Quaderni Storici, 1986, XXI, 63, p. 721-757.

Raggio, O., Faide e parentele. Lo stato genovese visto dalla fontanabuona, Turin, 1990.

Raggio, O., Kinship and lineage, in Historia de la Familia, una nueva interpretación de la sociedad Europea, (I Congreso Internacional, Murcia, 14-16 December), 1994 (forthcoming).

Reder, M., Conflictividad social en la Málaga del Antiguo Régimen, Baetica, 1992, 14, p. 273-296.

Reder, M., Conflictividad social en la Málaga del Antiguo Régimen (2a parte), Baetica, 1993, 15, p. 349-367.

Rodríguez, A., Morir en Extremadura. La muerte en la horca a finales del Antiguo Régimen, Cáceres, 1980.

Rodríguez, A., Las regulaciones del conflicto, Norba, 1981, II, p. 273-280.

Rodríguez, A., La historia de la violencia: espacios y formas en los siglos XVI y XVII, in Barros, C. (ed.), Historia a debate. II. Retorno del sujeto, Santiago de Compostela, 1995, p. 117-127.

Rodríguez, M.I., El perdón real en Castilla (siglos XIII-XVIII), Salamanca, 1971.

Rodríguez Molinero, M., Origen español de la ciencia del derecho penal. Alfonso de Castro y su sistema penal, Madrid, 1959.

Romero García, E., Procesos criminales en la Lérida de la segunda mitad del siglo XVII, I Congrés d'Historia de Catalunya, t. I, Barcelona, 1984, p. 497-502.

Sabean, D.W., Power in the Blood. Popular Culture \& Village Discourse in Early Modern Germany, Cambridge, 1987.

Sbriccoli, M., Fonti giudiziarie e fonti giuridiche. Riflessioni sulla fase attuale degli studi di storia del crimine e della giustizia criminale, Studi Storici, 1988, XXIX, p. 491-501.

Schafstein, F., La ciencia europea del derecho penal en la época del humanismo, Madrid, 1957 (1st ed. 1954).

Schulze, W., Peasant resistance in sixteenth- and sevententh-century Germany in a European Context, in Greyerz, K. von (ed.), Religion, Politics and Social Protest: Three Studies on Early Modern Germany, 1984, p. 61-98. 
Soman, A., Deviance and criminal justice in Western Europe, 1300-1800: an essay in structure, Criminal Justice History, 1980, p. 1-28.

Spierenburg, P.C., Elias and the history of crime and criminal justice: a brief evaluation, IAHCCJ Bulletin, 1995, 20, p. 17-30.

Suárez, V., Delitos, prisión y destierro en Canarias a fines del siglo XVIII, Congreso de Historia de Canarias, Las Palmas, 1991.

Thompson, E.P., Tradición, revuelta y consciencia de clase, Barcelona, 1979.

Thompson, E.P., Customs in Common, London, 1991.

Thompson, I.A.A., «A map of crime in sixteenth-century Spain», in War and Society in Habsburg Spain, Hampshire, XI, 1992 (1st ed. 1968), p. 244-267.

Tilly, Ch., Major forms of collective action in Western Europe, 1500-1975, Theory and Society, 1976, 3.

Tomás Y Valiente, F., El derecho penal de la monarquía absoluta. Siglos XVI-XVII-XVIII, Madrid, 1969.

Trasellin, C, Du fait divers à l'histoire sociale: criminalité et moralité en Sicile au début de l'Époque Moderne, Annales ESC, XXVII, 1973, p. 226-246.

Trinidad, P., Penalidad y gobierno de la pobreza en el Antiguo Régimen, Estudios de Historia Social, 1989, 48-49, p. 7-64.

Walter, J., Wrightson, K., Dearth and the social order in early modern England, in Slack, P. (ed.), Rebellion, Popular Protest and the Social Order in Early Modern England, Cambridge, 1984 (1st ed. 1976) p. 108-128.

Weisser, M.R., Crime and Punishment in Early Modern Europe, Londres, 1979.

Wormald, J., The blood feud in early modern Scotland, in Bossy, J. (ed.), Disputes and Settlements. Law and Human Relations in the West, Cambridge, 1983, p. 101-144.

Wrightson, K., Household and kinship in sixteenth century England, History Workshop Journal, 1991, XII.

Ylikangas, H., Major fluctuations in crimes of violence in Finland. A historical analysis, Scandinavian Journal of History, 1976, 1, p. 81-103.

Zorzi, A., Giustizia criminale e criminalità nell'Italia del tardo medioevo. Studi e prospettive di ricerca, Società e storia, 1989, XII, p. 923-965. 